\title{
International and national practice for estimating cash expenditures of road replacement, repair and maintenance
}

\author{
$V$ Gogolev$^{1}$, and $M$ Barysheva ${ }^{2}$ \\ ${ }^{1}$ Road Department, North-Eastern Federal University, 13 Krasilnikova Str., Yakutsk, 677013, Russia \\ ${ }^{2}$ Law College, North-Eastern Federal University, Yakutsk, 677013, Russia
}

\begin{abstract}
The paper considers the importance of the uninterrupted functioning of the transport network, which is the most important condition for eliminating the transport inaccessibility of Arctic territories of the regions, thus excluding transport discrimination of the population living in the Arctic zone of the Russian Federation. Besides, the paper provides a brief overview of international road repair and maintenance experience on the example of Norway, analysis of the standard for repair and maintenance of roads in the Russian Federation, proposals on the method of calculating the cash expenditures of replacement, repair and maintenance of roads in the Russian Federation. The Decree of the Government of the Russian Federation No. 658 dated May 30, 2017 approved the standards of financial expenditures and the rules for calculating the size of federal budget allocations for replacement, repair and maintenance of federal roads. However, at the moment, not all regions have updated the regulatory framework on the norms of financial expenditures and the rules for calculating budget allocations for replacement, repair and maintenance of regional and inter-municipal roads. The existing methodology for calculating the cost of repair and maintenance of roads in the Arctic territory of Russia does not fully provide the need to bring the existing roads into normal transport and operational condition for their safe operation. The analysis shows that there is no systematic work to ensure sustainable financing of the road economy in the republic and the road industry is financed at a level much lower than the actual needs.
\end{abstract}

\section{Introduction}

The development of the Arctic territories of the regions of the Russian Federation is largely determined by the intensification of the transport industry, which in the new market conditions is turning into a cross-industry system. Smooth operation of the transport network, including all modes of transport, is an essential condition for eliminating the transport inaccessibility of the Arctic territories of the regions, which excludes transport discrimination of the population living in the Arctic zone of the Russian Federation [5].

Efficient transport infrastructure should combine the characteristics of branching, technical infrastructure and the length of a single network of roads. This requires a combination of costs for the construction of new roads, as well as replacement, reconstruction, repair and maintenance of existing roads.

\section{Materials and Methods}

The existing method of calculating the cost of repair and maintenance of roads in the Arctic territory of Russia does not fully meet the requirements for bringing the existing roads into normal transport and operational condition for safe operation. Due to insufficient funding for the repair and maintenance of roads, the term "underrepair" has appeared and this "under-repair" is dramatically increasing every year.

In the current conditions, the most important task is to maintain the road network in an adequate transport and operational condition, taking into account the efficiency of measures for road users and for the national economy.

International practice in the field of estimating the financial expenditures of replacement, repair and maintenance of roads shows that the state authorities of foreign countries pay more attention to the quality of the execution of state contracts starting from design and survey work to the end of road construction. The quality of construction guarantees compliance with the standards of time between repairs, which is ultimately reflected in the planning of costs for repair and maintenance of roads. At the same time, sufficient state funds are allocated to maintain the transport and operational condition of state and regional roads. Funds are also allocated for municipal roads taking into account funding from the local budget. 


\section{Analysis of international and national practices}

Let us consider Norway as an example, since this country is part of the Arctic countries.

The natural and climatic conditions of Norway are most severe among all countries of Europe with excessive rainfall and quite long winters with low temperatures. In conditions of overwetting and long periods with negative temperatures, deformations of the roadway due to frost heaving of the foundation are one of the main problems during the operation of the country's roads.

In accordance with the road legislation, the Norwegian Ministry of Transport provides guidance on the maintenance of national roads and finances it. Norwegian Public Roads Administration (NPRA) acts on behalf of the Ministry of Transport. NPRA also manages provincial road maintenance activities implemented by the Provincial Councils. Municipalities finance and control the maintenance of municipal roads.

The Norwegian Public Roads Agency (Statens vegvesen) is the public authority responsible for national and circular public roads in Norway. The agency is subordinate to the Norwegian Ministry of Transport and Communications, manages the Public Roads Administration (Vegdirektoratet), and is one of the largest government agencies in Norway in terms of its budget. The agency is the distributor of funds for the repair and maintenance of public roads accumulated in the trust road fund.

The Norwegian Public Roads Administration takes precedence over the views of municipalities, since only locally they know everything about the region's different conditions and needs of a particular territory. Therefore, all road construction and repair projects pass through public hearings with the participation of municipalities, governmental agencies, landowners, road users and other persons interested in the development of the territory. It is they who make decisions based on the assessments and recommendations of the Norwegian State Road Administration and public hearings.

What is the situation with our national practice in this field?

According to the report of the Accounts Chamber of the Russian Federation, as part of the control activity "Checking the use of budget allocations aimed at maintaining public federal, regional and inter-municipal roads in 2018 and the past period of 2019”, on average, the maintenance of $1 \mathrm{~km}$ of the federal road network in 2019 amounted to 2.2 million rubles, while the maintenance of regional roads was almost 8 times less 288 thousand rubles per $1 \mathrm{~km}$. In general, on average, $29.6 \%$ of the normative need was allocated to regional or inter-municipal roads [1].

The Decree of the Government of the Russian Federation No. 658 of May 30, 2017 approved financial cost standards and rules for calculating the size of federal budget allocations for replacement, repair and maintenance of federal roads. However, at the moment, not all regions have updated the regulatory framework on the norms of financial expenditures and the rules for calculating budget allocations for replacement, repair and maintenance of regional and inter-municipal roads [3].

The length of the regional road network in the Republic of Sakha (Yakutia) is 13,079 km.

A characteristic feature of the Republic of Sakha (Yakutia) is that $73 \%$ of the regional road network is occupied by seasonal roads (ice - 35\%, land - 38\%) (Fig. 1.1) and these are mainly Arctic territories.

The estimated normative need for budgetary allocations for the maintenance of regional and intermunicipal roads in the Republic of Sakha (Yakutia) in 2019 amounted to 6017.19 million rubles. But it should be noted that the investment deflator index by year does not fully take into account the dynamics of the increase in the cost of goods, services (work) in the region, therefore it is proposed to use the consumer price deflator index in the region in a way that other constituent entities of the Russian Federation use it in similar calculation rules.

According to the Decree of the Government of the Russian Federation [3], the standards of financial expenditures for replacement, repair and maintenance of federal roads of category $\mathrm{V}$ are established in the amount of:

- maintenance - 806 thousand $\mathrm{rub} / \mathrm{km}$;

- repair - 4738 thousand $\mathrm{rub} / \mathrm{km}$;

- replacement - 12008 thousand $\mathrm{rub} / \mathrm{km}$.

The network of roads owned by the Republic of Sakha (Yakutia) consists of regional, inter-municipal and local roads. Annual surveys and diagnostics of existing roads carried out within the framework of legal regulations are designed to detect defects and violations in the transport and operational condition of road structures. Based on the acts of examination and diagnostics of the main regional and inter-municipal roads, the analysis and assessment of the public road network was carried out. The results of the assessment of the state of the network of regional roads in the main areas are satisfactory, and the assessment of intermunicipal and local roads is unsatisfactory. Next, let us consider the analysis of costs for replacement, repair and maintenance of roads.

According to the Decree of the Government of the Republic of Sakha (Yakutia) No. 352 dated August 27, 2009 [4], the standards of cash expenditures for the maintenance and repair of regional and inter-municipal roads of category IV with a transitional type of sandgravel coating were established in the following amounts:

- maintenance - 319 thousand $\mathrm{rub} / \mathrm{km}$;

- repair - 4,576 thousand rub/km;

- replacement - 8,614 thousand $\mathrm{rub} / \mathrm{km}$. 


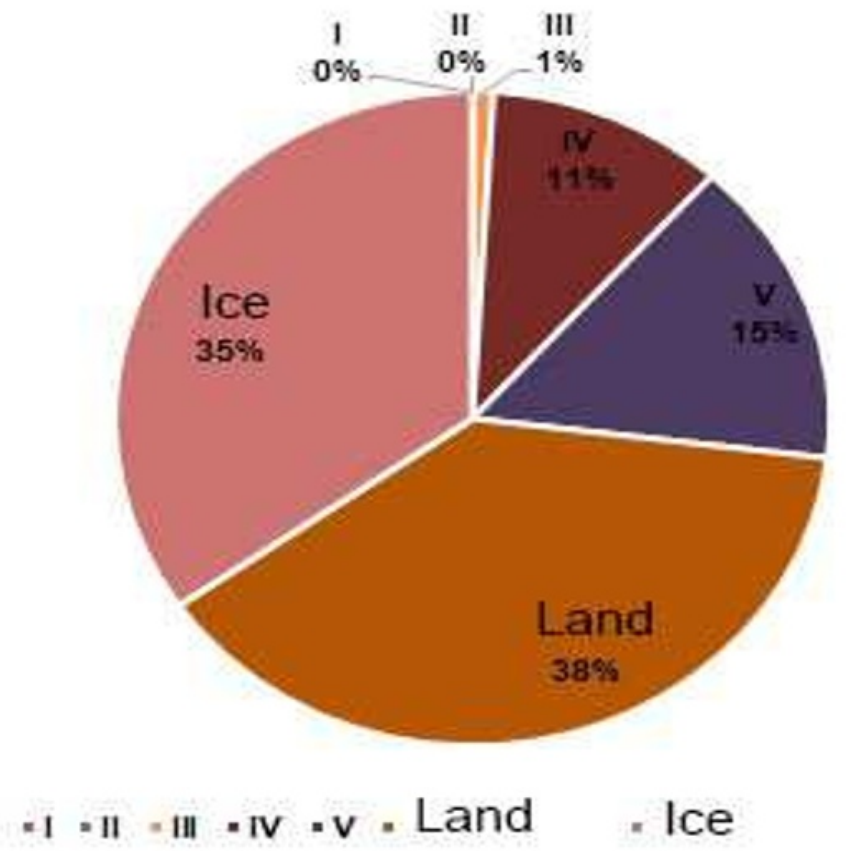

Fig. 1. Structure of regional and inter-municipal roads in the Republic of Sakha (Yakutia) in 2019 by categories

The difference between the norms of financial expenditures for replacement, repair and maintenance of federal roads of category $\mathrm{V}$ and for maintenance and repair of regional and inter-municipal roads of category IV with a transitional type of sand-gravel coating in the following amounts is as follows (excluding coefficients):

- maintenance - 2.51 times;

- repair - 1.03 times;

- replacement - 1.39 times.

As a result, for the maintenance of $1 \mathrm{~km}$ of roads of regional and inter-municipal significance from the Road Fund of the Republic of Sakha (Yakutia) in 2019, the provision of regulatory requirements was $27 \%$ or lower than the level in the whole of the Russian Federation (29.6\%). That does not allow to maintain the proper technical condition of highways. Taking into account the additional funds allocated for the implementation of the national project "Safe and High-quality Highways" (hereinafter referred to $\mathrm{SHH}$ ), the provision of regulatory requirements has increased to $48 \%$.

Consequently, the full scope of work on the maintenance of the regional road network is not carried out. In fact, in 2019, 61\% of the regional road network of the RS (Yakutia) funded by their road fund was covered, where maintenance work was carried out with an average cost of 157.7 thousand rubles per $1 \mathrm{~km}$, which is $45 \%$ lower than the all-Russian level (288.1).

The insufficient level of funding for the repair and overhaul of the regional road network of the Republic of Sakha (Yakutia) causes the following negative consequences:

- does not allow to maintain the proper technical condition of roads and leads to a decrease in the level of maintenance of roads;
- the low level of maintenance of highways leads to an increase in the number of accidents, including due to the shortcomings of the transport and operational condition of sections of the road network;

- the limited financial security of the work leads to non-compliance with the inter-repair deadlines with the required increases, taking into account Decree of the Government of the Russian Federation No. 658.

The analysis showed that at the moment there is a situation in which the financial independence of the constituent entities of the Russian Federation in the road economy is quite limited. To adequately finance the replacement, repair and maintenance of roads at the regional level, each constituent entity needs to bring the regulatory framework in line with existing state programs, since the federal budget is spent $70 \%$ through the program method. This approach is caused by clearer targeted budget spending within the normative, estimated pricing in the road industry, which has developed over a quite long period of time.

To date, there are no legally established criteria for assigning roads against a certain level of their maintenance, as well as the mechanism, according to which Rosavtodor distributes budget allocations for the maintenance of roads to its subordinate institutions.

The law only stipulates the general standard for the size of budget allocations, which is used in the formation of the federal budget for the next year and the planning period. As a result, in different regions the volume of funds is quite different from the standard. The powers of regional authorities and local self-governmental bodies in the field of the use of regional, inter-municipal and local motor roads and the implementation of road 
activities provided for by the Federal Law of 08.11.2007 No. 257-FZ "On Roads and Road Activities in the Russian Federation and on Amendments to Certain Legislative Acts of the Russian Federation", are not fully regulated $[2,3]$.

So it turns out that in disregard of paragraphs 11 of article 12 and 13, paragraphs 2 and 3 of article 33 and 34 of the Federal Law No. 257-FZ and the Decree of the Government of the Russian Federation No. 658 of May 302017 the approved funding standards for replacement, repair, and maintenance of regional, inter-municipal and local roads are greatly underestimated. As a result, we get "under-repair", which is increasing from year to year.

The analysis shows that there is no systematic work to ensure sustainable financing of the road economy in the republic and the road industry is financed at a level much lower than the actual needs.

Insufficient funding for the repair and replacement of the regional road network in the Republic of Sakha (Yakutia) does not allow maintaining the proper technical condition of roads and leads to a decrease in the level of maintenance of roads and to non-compliance with the period between repairs with the need to increase it. Thus, to form a system of budgetary financing for road replacement, repair and maintenance at the regional level, there is a need to establish a road planning system for the reporting period, to adopt regulatory acts governing the procedure for assessing the technical condition of roads and artificial structures on them, to specify the procedure for diagnosing the state of roads, to update the standards of financial expenditures for maintenance and repair of regional and inter-municipal roads from the budget of the the Republic of Sakha (Yakutia), to modernize the methodology for their calculation in accordance with regional features.

Within the framework of the Safe and Quality Automobile Roads (SQAR) national project, the amount of funding for the region's road fund in terms of interbudget transfers from the federal budget directly depends on the competent, systematic approach of executive and legislative authorities of the constituent entities of the Russian Federation to the preparation of regional road projects, the availability of regulatory acts governing replacement, repair and maintenance of roads.

\section{Conclusion}

The discrepancy of standards of financial expenditures for replacement, repair and maintenance of regional, intermunicipal and local roads, rules of calculation of the amount of regional and local budget allocations for specified purposes, techniques of their calculation does not allow the regional and local authorities properly controlling their functions:

- ensuring safety of regional, inter-municipal and local roads;

- conducting road activities on regional, intermunicipal and local roads;

- timely planning and calculating of expenses for the next fiscal year necessary for replacement and repair of regional, inter-municipal and local roads.
In this regard, it is necessary to develop and approve new financial cost standards for replacement, repair and maintenance of regional, inter-municipal and local roads and rules for calculating the amount of regional and local budget allocations for these purposes, as well as a methodology for calculating them.

\section{Acknowledgements}

According to the research project No. AAAA-A20120121490014-1, the study is funded by the Automobile Roads Department of the Republic of Sakha (Yakutia).

\section{References}

1. Chamber of the Russian Federation, Report on the results of the control activity "Verification of the use of budget allocations aimed at the maintenance of roads of federal, regional and inter-municipal public in 2018 and in the to date period of 2019" (with control and accounting bodies of the constituent entities of the Russian Federation), Retrieved from: https://ach.gov.ru/upload/iblock/c8e/c8e8afe3c8e 348dc67f36bd6e24bf5c8.pdf. (2020)

2. Federal Law No. 257-FZ "On Roads and Road Activities in the Russian Federation and on Amending Certain Legislative Acts of the Russian Federation" Retrieved from: http://www.consultant.ru/document/cons doc LA W 72386/. (2007)

3. Decree of the Government of the Russian Federation No. 658 "On Financial Cost Standards and Rules for Calculating the Size of Budget Allocations of the Federal Budget for Replacement, Repair and Maintenance of Federal Roads". Retrieved from: http://base.garant.ru/71689744/.

4. Resolution of the Government of the Republic of Sakha (Yakutia) No. 352 "On the norms of cash expenditures for the maintenance and repair of regional and inter-municipal roads and the rules for their calculation". Retrieved from: http://base.garant No .t.ru/26715703/\#xzz6aEz0Yf RC

5. V.N. Bugromenko, Izvestia RAS. Series: Geography. 4, 7-16, (2010). 